\title{
Pedagogical Conditions of Developing Professional Culture in Law Students
}

\author{
Tetiana V. Kononenko ${ }^{1}$, Halyna V. Mukhina ${ }^{1}$, Kateryna V. Ponomarenko ${ }^{1}$ \& Olha O. Novikova ${ }^{1}$ \\ ${ }^{1}$ Social-Humanitarian Department, Donetsk Law Institute MIA of Ukraine, Kryvyi Rih, Ukraine \\ Correspondence: Olha O. Novikova, Donetsk Law Institute MIA of Ukraine, 21 Stepana Tilhy str., Kryvyi Rih, \\ 50065, Ukraine.
}

Received: June 10, 2020

Accepted: August 3, 2020

Online Published: August 4, 2020

doi:10.5430/ijhe.v9n7p36

URL: https://doi.org/10.5430/ijhe.v9n7p36

\begin{abstract}
The article substantiates the pedagogical conditions of developing professional culture in law students. To this end, the authors reviewed scientific (pedagogical, psychological, legal) literature, taking into account particularities of professional activity of future lawyers, as well as educational standards of training law students in higher educational institutions (HEIs) of Ukraine, and the component structure of professional culture of future lawyers. The above steps suggested that ensuring efficient development of the phenomenon under study is possible through the realization of a set of pedagogical factors, namely: formation of professional-subject constructs of professional culture of law students in the process of solving simulated professional situations; involvement of law students in professional activity through legal clinics; creation of a professional and cultural educational environment in HEIs. We selected the pedagogical conditions with emphasis on the components of professional culture of law students. Thus, each specific pedagogical condition was directed to the formation of a specific component of the phenomenon under study. We applied A number of methods of scientific knowledge and special techniques in the course of the experimental research to study the level of the development of professional culture in law students. To check the effectiveness of the implementation of certain pedagogical conditions, we conducted a pedagogical experiment, which consisted of a series of successive stages. The students of the control groups studied with the use of the traditional system of training law students. In the experimental groups, pedagogical conditions of developing professional culture in law students were realized by implementation of competent, contextual, systematic approaches and innovative methods were used during classes in a number of professional subjects. The analysis of the indicators of the level of professional culture development in law students shows that there are students with low levels in both categories of groups. Therefore, the improvement of the professional training of lawyers in the direction of further development of their professional culture according to our method becomes topical, since significant positive results were obtained in the experimental groups.
\end{abstract}

Keywords: law students, professional culture, higher educational institutions, pedagogical conditions, legal clinic

\section{Introduction}

Modernization of the state economy requires qualified lawyers. In recent years, a significant strengthening of the role of law in public life has led to significant changes in the system of training of lawyers in Ukraine. Academic legal science must meet the requirements of students in terms of different spheres of public life, such as economics, politics, culture, etc. Reforming the state and economic system requires an appropriate response from legal education, leads to increased prestige of legal professions, improved social status of lawyers, and increased level of remuneration of their work. The challenges of a changing society make new demands on the personality of lawyers and their role in society. The law students must operate in the space of modern democracy, which provides a high level of responsibility for the legal solution, its preliminary justification based on the analysis of the social process, trends of strengthening law and order in the country. In this regard, educational science pays considerable attention to the problems of developing the competence of the future lawyers.

Modern lawyers must be mobile, sociable, must be in demand in the labour market. This requirement of the state to young specialists is due to dynamic changes in various spheres of society and the need for the individual to adapt to them. The task of higher educational institutions (HEIs) is to graduate specialists with a high level of theoretical and legal knowledge, as well as good practical training in the legal field. However, even these requirements for the training of lawyers are not exhaustive. The activities of a lawyer include the protection of the interests and rights of 
the individual, his freedom and property, the interests of the state and society from unlawful encroachments. Therefore, a lawyer needs to have such qualities as social adaptability, high level of intellectual development, neuropsychological stability, communicative competence and others. The future bachelor of law must, first of all, have a clearly established professional position. It is the contextual training that can ensure the formation of the professional position of specialists, while psychological, pedagogical, methodological and other factors are a background for these qualities.

In the context of building a democratic state of law, attention is paid to improving the professional competence of lawyers. This leads to the provision of quality training of highly qualified, competent specialists in accordance with the requirements of the state, society, needs and abilities of an individual (Annan-Diab \& Molinari, 2017). Higher education plays a leading role in the formation of cultural values of society (Bakhov, 2014), increasing the scientific and intellectual potential of the country (Maravilhas, 2015), educating independent, initiative and responsible members of society capable of effectively interacting in the fulfilment of social, industrial and economic goals (Bhabha, 2014).

Addressing the new challenges that are emerging at the current stage of the development of Ukrainian state poses the problem of qualitative training for future lawyers, including bachelors of law as a priority (Bryant et al., 2014). There is a sharp gap between the quality of training of a future lawyer and the demands that society makes to specialists in the workplace (Greiner, Pattanayak, \& Hennessy, 2013; Tække \& Paulsen, 2017). The process of developing professional culture of a lawyer that would perform complex professional functions should be arranged in accordance with current realities that reflect the dynamics of legal practice (Jones, McFaul \& Ryan, 2017).

Higher professional education aimed at training future lawyers, along with the formation of key professional competencies, is a mechanism for developing their professional culture (Maharg, 2016). This phenomenon constitutes the context of the professional activity of a lawyer, generalizes and updates the system of ideas about the specifics of the profession, as well as generates knowledge and skills, which depend on the effectiveness of legal activity, which is to ensure law and order (Kozhemiako, 2013). According to this thesis, the professional culture of a lawyer is a professionally significant personal quality of a specialist in the system of professional ethical standards and values (Nasilenko, 2014; Olasolo \& Wilson, 2016).

A detailed analysis of the curricula for training future lawyers in HEIs of Ukraine has shown that the modern higher professional education is, first of all, aimed not at the formation of the academic system of the level of knowledge, but at the achievement of professional competence by a specialist. After all, the future lawyer must have a creative approach to the practical solution of professional tasks; have the ability to perform a professional duty with a high level of efficiency.

In this regard, competence is the necessary quality of a specialist, which allows him to systematically apply knowledge, skills and abilities, successfully solving problems, contradictions and tasks in a personal, professional and social context (Tejedor, Segalas \& Rosas-Casals, 2018). At the same time, summarizing the analysis of the results of the survey of students of legal specialties aimed at determining the current level of the development of professional culture showed that the formation of this phenomenon as one of the components of professional competence of future lawyers through the traditional training system is ineffective. This urged the need to isolate the pedagogical conditions that will ensure development of professional culture of law students.

In order to explain the author's view on the factors that will contribute to the intensification of professional training of future lawyers, let us consider the semantic and etymological content of the categories of "condition", "pedagogical condition". There are different types of pedagogical conditions in the theory and practice of pedagogical science: organizational and pedagogical (Svetlichny, 2016; Zoshiy, 2018, etc.), psychological and pedagogical (Tsiganyi, 2016) and didactic (Bratkova, 2018). All of these types extend and complement the definition of the term of "pedagogical conditions", and also make the pedagogical process more comfortable and productive.

A number of experts consider it necessary to reflect a set of organizational forms (Bondarenko, Bodenchuk, Krynytska \& Gayvoronska, 2019), material and objective opportunities for education of people (Svetlichny, 2016) in the concept of "pedagogical conditions", as well as recognize the basic grounds for unification of different activities to manage the process of development of a professional pedagogical culture of an individual as the pedagogical conditions (Tsiganyi, 2016).

We consider Khushbakhtov's (2015) position to be correct, who considers that the term of "pedagogical conditions" has the following characteristic features: material and technical resources of the educational space; a number of methods of psychological and pedagogical influence on the process of becoming a future specialist during training at the HEI; facilitative interaction between lecturers and students. 
In the light of research into developing professional culture of law students, pedagogical conditions have been interpreted as a series of interrelated activities aimed at ensuring the development of professional knowledge, skills and abilities as components of the phenomenon under study. These conditions are the result of purposeful planned selection, construction and application of content elements, methods (techniques) to achieve the goal of experimental activity - a high level of professional culture of law students.

In order to single out the effective pedagogical conditions of the study, the modern achievements of scholars who devoted their studies to the problem of professional training of future lawyers were analysed. In particular, the works deal with the professional characteristics of lawyers, as well as the psychological and pedagogical component of the development of these characteristics in HEIs (Bartoli, 2015). A number of researchers urge the need to use the didactic potential of psychological and pedagogical subjects that contribute to the formation of future specialists: pedagogical culture, psychological culture, ability to self-education, formation and development of professional consciousness, professional self-concept, managerial skills, formation of personal qualities etc. (Bautista, 2014; Finkelstein, 2015; Giamellaro, 2014). The researchers also study the peculiarities of pedagogical preparation of future lawyers, studying the theoretical, practical, methodological foundations of pedagogical culture of bachelors and students, communicative culture, communicative knowledge, skills, professional qualities, etc. (Shay, 2015). In accordance with the selected objects and subjects of study, the authors formulate pedagogical conditions for their provision on the basis of experimental studies.

A detailed analysis of the scientific (pedagogical, psychological, legal) literature (Salomatin, 2015), taking into account the peculiarities of the professional activity of future lawyers, appealing to the educational standards of preparation of law students in HEIs of Ukraine and the component structure of the professional culture of future lawyers allowed assuming that ensuring the effectiveness of the formation of the phenomenon under study is possible through the implementation of a set of pedagogical factors, which, in our opinion, include:

- formation of professional-subject constructs of professional culture of law students in the process of solving simulated professional situations;

- involvement of law students in professional activity in legal clinics;

- creation of a professional and cultural educational environment in HEIs. It should be noted that in the implementation of the above pedagogical conditions, their close relationship is of particular importance. At the same time, we consider it appropriate to emphasize that the pedagogical conditions were selected with the emphasis on the components of professional culture of law students. Thus, each specific pedagogical condition was directed to the formation of a specific component of the phenomenon under study.

\section{Materials and Methods of Research}

The general logic of the experimental work on the introduction of pedagogical conditions for developing professional culture of law students involved the organization of a pedagogical experiment, which consisted of a series of successive stages. Research as a complex set of arranged scientific, theoretical, methodical and organizational measures had several stages - preparatory (search and organizational) stage (review of scientific literature), summative assessment (establishing the actual level of the development of professional culture of law students), formative assessment (realization of author's pedagogical conditions in the educational process of HEIs of Ukraine), the final (final-corrective) stage (detailing of the dynamics of changes in the formation of the components of professional culture of future lawyers in the context of traditional and experimental training) aimed at achieving research goals and objectives.

The complexity, versatility and interdisciplinary status of the scientific problem of the introduction of pedagogical conditions for developing professional culture of law students determine the need for its study in the coordinate system given by different levels of methodology of science. The scientific tradition has adopted the interpretation of methodology as the doctrine of the scientific method of cognition or the system of scientific principles being the basis of research (Fernandes, 2015; Jacobowitz, 2015; Romanenko \& Chaplay, 2016; Strevens \& Field, 2019; Verbitskiy, 2015 , etc.). Using this interpretation, we determine and substantiate general scientific methodological foundations (methods of cognition) of research. The application of the historical approach allows investigating the development and emergence of the problem of the use of innovative teaching methods in the professional training of future lawyers in social practice and science. An important place in the research is given to the systemic approach, which is realized during the analysis of the process of professional training of law students and its main components in multifaceted relationships (structure, interconnections of elements and phenomena, their subordination, hierarchy, functioning, integrity of development, system dynamics, essence and features, factors and conditions), which implicitly includes a 
number of methods, forms, means, which are revealed in the ways of educational actions of the subjects of research in the direction of acquiring professional knowledge, abilities and skills of future lawyers. The cognitive principle used in the study is general scientific and related to the general philosophical theory of cognition.

Among the methods of scientific knowledge, the methods of empirical research (observation, questioning, experiment, etc.), as well as methods used at the empirical and theoretical stages of research (abstraction, analysis and synthesis, modelling, product analysis, document analysis, etc.) were of the greatest use in the process of introducing pedagogical conditions for the formation of professional culture of law students. Thus, the method of observation has taken the leading place in identifying the behavioural characteristics of students studying at the faculties of law. In our study, this method was used to collect and summarize primary information obtained as a set of empirical statements.

The survey was used at all stages of information collection. Questionnaires were the main documents to collect the primary information. The method of studying the attitude of students to the phenomenon of "professional culture of lawyer", including theoretical and practical questions regarding the level of professional knowledge of future bachelors of law was interviewing using the questionnaire The Level of Professional Culture of Future Lawyers.

In order to study the materials related to the planning and implementation of the various types of activities performed by students in HEIs, the method of analysis of the products of the activity is used in the work. In particular, in the course of educational and research activities, academic achievements of students were formally evaluated, which was recorded in academic registers, protocols, articles, results of midterm examinations and exam sessions. The analysis of these materials (results of tests, abstracts and term papers, etc.) allowed clarifying the degree of objectivity and accuracy of data obtained through the use of other methods, as well as clarifying the importance of qualitative assessment of students' academic achievements to determine the professional culture of law students.

In the process of introducing pedagogical conditions for the formation of professional culture of law students, the method of vertical and cross sections was applied, which reveals chronological aspects of the study. Through cross sections, empirical data were obtained on a wide array of subjects. Cross sections made it possible to obtain data by comparing features of different objects of study. With their use the structure and peculiarities of the level of development of professional values, some forms of educational activity of law students were studied.

The method of vertical sections consisted of repeatedly referring to the same objects of study for a certain period. Its main advantage is the ability to trace the dynamics of the studied parameters, the tendency to their change in quantitative and qualitative terms. Using the method of vertical sections, the dynamics of the levels of professional culture of future lawyers were studied according to the indicators of all components. The coverage of this method was 4 years.

The expert evaluation method had little use in the study. It has been used to interview a special group of experts lecturers of law - to identify the specific variables needed to evaluate students' academic achievements, judgments and behaviours. The experts were selected on the basis of their formal professional status. The use of the expert evaluation method allowed objecting the results of our research.

Methods of mathematical statistics (Fornell \& Larcker, 1981) with the calculation of Fisher's criterion were applied to process the obtained results and establish quantitative and qualitative relationships between phenomena and processes.

\section{Results}

The first pedagogical condition for the formation of professional culture of future lawyers is the formation of professional and subjective constructs of professional culture of law students in the process of solving simulated professional situations. A pedagogical construct is a model of the matrices of the construction and transformation of objective knowledge that cause the quality and possibilities of setting and solving professional and pedagogical tasks (Josephsen, 2015).

The evaluative system that an individual uses to classify different objects in his or her living space can be determined as a personal construct - a term proposed in the personality psychology by J. Joseph (2015) to refer to the cognitive patterns that a person "creates and then tries to adjust to those realities that make up this world" (Josephsen, 2015). Constructs are used to predict repetitive events that allow an individual to not only explain another person's behaviour, but also to design one's own, since the construct indicates the actual program of such behaviour.

The second pedagogical condition for the formation of professional culture is the involvement of future lawyers in professional activity in legal clinics, which we consider as a program of additional education for acquiring practical 
skills of legal activity and the development of professional culture of the future lawyers without breaking from the basic process of education.

In the process of realization of the second pedagogical condition, the legal clinics were established on the basis of HEIs which train law students in Ukraine for the purpose of delivering consultations to the population. The practice of establishing such clinics is now being actively implemented in Europe and the United States (Olasolo \& Wilson, 2016). Law students were specialists in such clinics. In legal clinics, future specialists under the supervision and guidance of their lecturers, provided legal aid to socially disadvantaged citizens, provided legal protection of public interests, assisted with the organization and maintenance of websites, provided assistance to small businesses in the area. The clinical program involved students of $3^{\text {rd }}$ and $4^{\text {th }}$ years of study; supervisors, clinic administrators (students of the last years of study or post-graduate students, faculty or experienced specialists); clinics' clients - citizens who are unable to obtain quality legal aid free of charge, as well as small businesses.

The third pedagogical condition for developing professional culture of law students is the creation of a vocational and cultural educational environment in HEIs, which integrates system-activity, personality-oriented, competent and contextual approaches.

One of the factors influencing the development of professionalism of future lawyers is the professional and cultural educational environment of HEIs. In today's socio-economic conditions, the education system is regarded as a system of specially organized, pedagogically appropriate conditions for the personality formation, social and cultural self-development of the young generation. The higher education organization as an element of the education system retains this essential characteristic (Kalaur, Sloma \& Hnativ, 2017).

The formation of the cultural and educational environment of HEIs as a condition for successful socio-cultural development of an individual has an objective conditionality. The topicality of the problem of optimization of the cultural, educational and developmental environment of HEIs is determined by a number of pedagogical contradictions between:

- complication of tasks of professional activity of specialists in the context of modern society and necessity of modernization of the existing system of their preparation in higher educational institutions;

- the existing potentials of the cultural and educational environment of the modern HEI and their real use in the process of personal and professional formation of a young specialist in law;

- the objective necessity to create pedagogical conditions that ensure the productivity of the process of personal and professional formation of specialists in the cultural and educational space of a modern HEI and insufficient organizational and pedagogical support of this process.

The cultural and educational environment of a modern HEI accumulates purposefully created conditions for the interaction of the subjective world of the personality of a future lawyer with the objective world, which create a direct or indirect influence on the formation of a competitive specialist by providing opportunities for the development of skills and competences.

It is possible to conclude that the pedagogical conditions for the formation of professional culture in law students are a set of conditions and factors that contribute to the formation of competent professionals from the standpoint of a systemic approach, ensuring the formation and development of pedagogical culture, communicative culture, communicative skills and abilities, personal qualities and professional competencies.

\section{Discussion}

To confirm the effectiveness of the implementation of the above pedagogical conditions for the formation of professional culture in law students at the beginning of the experiment, an analysis of the existing level of the development of the studied phenomenon in future lawyers was carried out (summative stage of the experiment).

The conducted analysis of the results of survey, testing, individual discussions with students allowed to establish the level of development of professional culture of 384 law students in three HEIs of Ukraine at the stage of the summative assessment. It was found that students showed different levels (high - medium - low) in the following aspects of the level of development of professional culture:

1) awareness of the peculiarities of professional communication and interaction in the "lawyer-client" system (12.5\% $48.7 \%-38.8 \%$, respectively);

2) a complex set of competences of value and semantic orientation of professional activity of future lawyers, cultural cognitive and educational-cognitive competences, communicative competences which provide exchange of 
information on professional issues for creation of own model of professional culture of future lawyers $(8,59 \%$ $53,39 \%-38.02 \%$, respectively);

3) by the indicators of self-assessment of the level of development of their own professional culture $(9.38 \%-38.28 \%$ $52.34 \%$, respectively);

4) by the level of students' readiness to perform practical professional actions in future professional activity $(7.29 \%$ $47.92 \%-44.79 \%$, respectively).

Thus, the general status of the development of professional culture of law students varies within the following limits:

- by high level indicators: $7.29 \%-12.5 \%$;

- by medium level indicators: $38.28 \%-53.39 \%$;

- by low level indicators: $38.02 \%-52.34 \%$.

The diagnostics confirmed the following:

- future lawyers do not have an established idea about the image of their future professional realization; a large number of students do not knowingly intend to conduct activities in this field; future lawyers do not express a strong desire to work in their profession; students are not motivated to realize themselves as a lawyer; future lawyers have insufficient knowledge of the nature of their professional activities, so they do not always understand the importance of professional communication skills, etc. The results obtained underline the topicality of our research and indicate the need for the realization of the author's pedagogical conditions.

At the stage of incoming control with the students of control and experimental groups, the following activities were carried out: through survey, using the questionnaires used during the summative stage of the study, the level of awareness of students from different branches of law was established, motives and value attitude of students to their future professional activity were determined; manifestation of interest in mastering professionally and personally important pedagogical knowledge and skills by a future lawyer; persistence of motivation to master professional and pedagogical competence; aware of the need for thorough pedagogical training; rapid testing to establish the level of knowledge in the field of law, information about forms, methods, techniques and means of pedagogical influence, understanding of the mission of the lawyer and his functional responsibilities, awareness of the importance of knowledge in the field of pedagogy and psychology for solving legal problems; observation of students while working in legal clinics to diagnose practical skills of professional communication with clients; conversations with students with the purpose of establishing their readiness for organization and systemic scientifically grounded communication interaction in future professional activity. The incoming level of the level of development of professional culture in law students was established according to the criteria and indicators of the phenomenon under study.

The students of the control groups were trained with the use of the traditional system of training law students. The pedagogical conditions for the formation of professional culture in law students were realized in experimental groups through the implementation of competent, contextual, systemic approaches, and innovative methods in a number of professional subjects were used during classes.

Students in both categories were asked to keep Personal Achievements Records, which was checked by teachers on a monthly basis. Generalizations about the level of development of professional culture in law students were made on the basis of observations of students during their work in legal clinics, assessment of the level of their communicative preparation, analysis of the Personal Achievements Records.

We attached particular importance to the content of each student's Personal Achievements Records. The attention was focused on the systemic filling of these Records, conducting self-examination on the regularity and systematic nature of self-education for enriching communication skills, student's substantiating scientific approaches to the use of certain strategies of solving problems of the client of the legal clinic, student's self-assessment of the effectiveness of these actions for the development of their own professional culture.

As there were no students with a completely undeveloped professional culture during the experimental study, the results of the experiment were therefore determined by high, medium and low levels.

Let us note that the realization of pedagogical conditions for the development of professional culture in law students was characterized by some features, including: the indicators of the final levels of development of professional culture in law students were determined at the final stage of the formative assessment, which were compared with the indicators obtained on the basis of incoming control; the analysis of the obtained experimental data was carried out in order to check the effectiveness of realization of pedagogical conditions for the formation of professional culture in law 
students; the obtained indicators were systematized at the formative stage of the experimental and mathematical processing of digital data was applied on the basis of proving the reliability of the results of the experiment using methods of mathematical statistics.

The results obtained at the stage of incoming and final control were systematized and generalized. The obtained indicators of the levels of professional culture in law students at the stages of incoming and final control were compared using Table 1.

In order to perform mathematical calculations of the probability and reliability of the experimental study, each of the levels was marked with a numerical indicator: high - 5 points; average - 4 points; low - 3 points.

To establish the arithmetic mean of the level of development of professional culture in law students in each group and at each stage of the experimental study, a mean indicator was used, designated as MI, seen to the Table 1.

Table 1. Indicators of the level of development of professional culture in law students at the stage of incoming and final control

\begin{tabular}{|c|c|c|c|c|c|c|c|c|c|}
\hline \multirow{3}{*}{ Groups } & \multirow{3}{*}{$\begin{array}{l}\text { Stage of } \\
\text { control }\end{array}$} & \multirow{3}{*}{$\begin{array}{l}\text { Number } \\
\text { of } \\
\text { students }\end{array}$} & \multicolumn{6}{|c|}{$\begin{array}{l}\text { Indicators of the level of development of professional culture in } \\
\text { law students }\end{array}$} & \multirow{3}{*}{ MI } \\
\hline & & & \multicolumn{2}{|c|}{$\begin{array}{l}\text { High } \\
\text { (5 points) }\end{array}$} & \multicolumn{2}{|l|}{$\begin{array}{l}\text { Sufficient } \\
\text { (4 points) }\end{array}$} & \multicolumn{2}{|c|}{$\begin{array}{l}\text { Satisfactory } \\
\text { (3 points) }\end{array}$} & \\
\hline & & & $\begin{array}{l}\text { Number } \\
\text { of } \\
\text { students }\end{array}$ & $\%$ & $\begin{array}{l}\text { Number } \\
\text { of } \\
\text { students }\end{array}$ & $\%$ & $\begin{array}{l}\text { Number } \\
\text { of } \\
\text { students }\end{array}$ & $\%$ & \\
\hline \multirow[t]{2}{*}{$\mathrm{CG}$} & IC & 105 & 10 & 9.52 & 43 & 40.95 & 52 & 49.52 & 3.60 \\
\hline & $\mathrm{FC}$ & 104 & 13 & 12.5 & 46 & 44.23 & 45 & 43.27 & 3.69 \\
\hline \multirow[t]{2}{*}{ EG } & IC & 108 & 9 & 8.33 & 44 & 40.74 & 55 & 50.93 & 3.57 \\
\hline & $\mathrm{FC}$ & 107 & 39 & 36.45 & 46 & 42.99 & 22 & 20.56 & 4.16 \\
\hline
\end{tabular}

Comparative analysis of indicators of the levels of development of professional culture in law students at the stage of incoming and final control, presented in Table 1, allows making the following generalizations:

1. According to the results of incoming control, mean indicator (MI) of professional culture in law students of control and experimental groups had almost the same value: 3.6 points in the CG and 3.57 points in the EG. This testifies to the students' involvement in the process of experimental study under the same conditions.

2. Comparison of the indicators of professional culture in law students at the stages of incoming and final control proves the effectiveness of our experimental methodology. Since the total number of students in the CG and the EG was not the same, we compared the percentages.

Thus, in terms of the indicators of high level, the number of such students increased in the control groups from $9.52 \%$ to $12.5 \%$ (by $2.87 \%$ ), and in the experimental groups - from $8.33 \%$ to $36.45 \%$ (by $28.12 \%$ ), which is $25.25 \%$ more than in the control groups.

The number of students who showed a medium level of professional culture varied from $40.95 \%$ to $44.23 \%$ (3.28\%) in the CG, and from $40.74 \%$ to $42.99 \%$ in the EG (by 2.25\%). The small increase in the number of such students in the EG was due to the fact that the majority of students with a medium level increased their level to high.

According to the indicators of the low level of professional culture in the control groups, there was a decrease in the number of students from $49.52 \%$ to $43.27 \%$ (by $6.25 \%$ ), and in the experimental groups - from $50.93 \%$ to $20.56 \%$ (by $30.37 \%$ ), which is $24.12 \%$ more than in the CGs.

3. According to our method, better efficiency of the development of professional culture in law students in the EG is confirmed by the dynamics of mean indicators (MIs). Thus, in students of control groups, the value of MI changed during the formative assessment from 3.60 points to 3.69 points (i.e., by 0.09 points), and in the experimental groups this indicator increased from 3.57 points to 4.16 points (by 0.59 points), which is 0.5 points better than in the CG.

For visual analysis of the dynamics of the effectiveness of the experimental study, histograms were built according to the indicators of the levels of the development of professional culture in law students, what can be seen from the Figure 1, and according to the mean indicators, seen to the Figure 2. The comparison of the histograms indicates that 
there are more significant changes in the levels of development of professional culture in the experimental groups than in students of the control groups of law students.

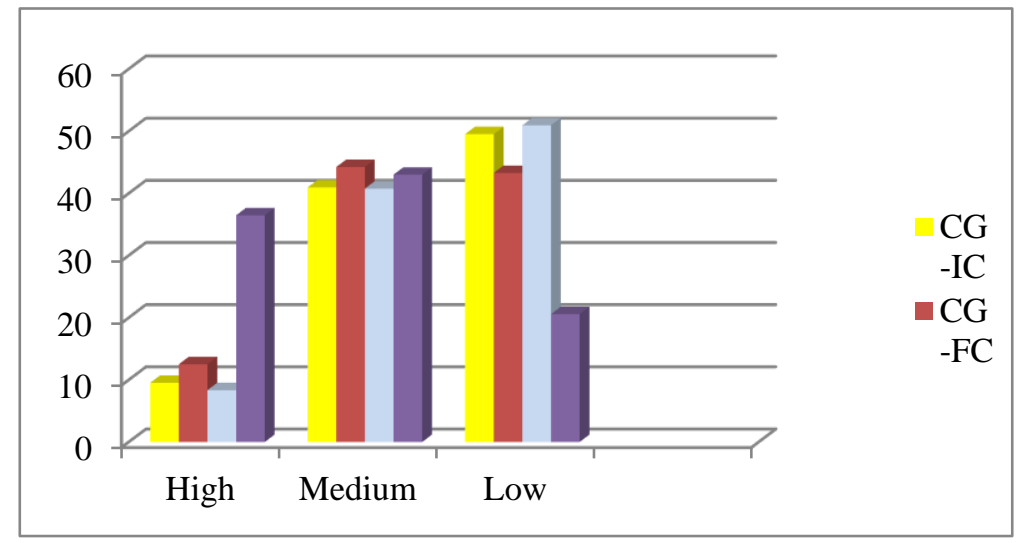

Figure 1. Dynamics of the indicators of professional culture levels in law students

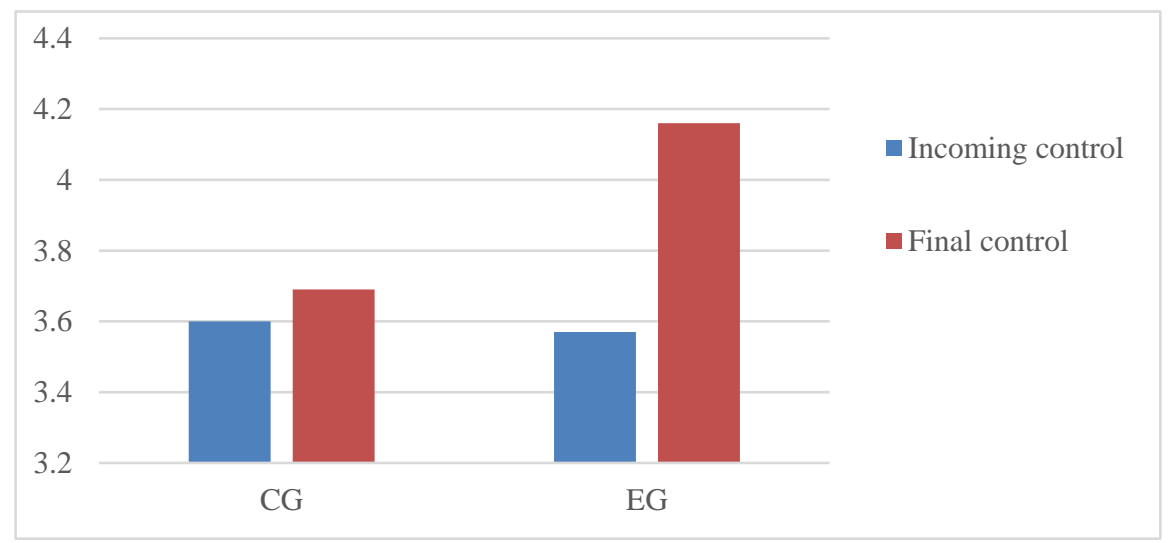

Figure 2. Dynamics of the mean values of professional culture in law students of control and experimental groups

The analysis of the indicators of the levels of professional culture in law students shows that there are students with low levels in both categories of groups. Therefore, the improvement of the professional training of lawyers in the direction of further development of their professional culture according to our methodology becomes topical, as significant positive results were obtained in the experimental groups. As our experimental research was conducted with the students of the $1^{\text {st }}$ and $2^{\text {nd }}$ years of study, it is advisable to continue the development of professional culture in law students in the following years of study.

Mathematical statistics methods applied in professional pedagogy were used to verify the results obtained and to process the results of the pedagogical experiment (Kyveryalg, 1980). In our study, these methods were comparison of the parameters of the universe (mean values and variances) using the F-criterion. The F-value table was used as the basis (Kyveryalg, 1980) to compare the numerical values of the empirical F-criterion (calculated on the basis of the digital data obtained during the experiment) and the theoretical F-criterion presented in the standard table.

According to the null hypothesis of our study, the difference in the indicators of the levels of professional culture in law students of control groups is the result of the natural course of the educational process. An alternative hypothesis was the assumption that the difference between the incoming and final control indicators in the experimental groups is due to the deliberate application of pedagogical conditions for the development of professional culture in law students in the study. The null and alternative hypotheses were compared to test the validity of the study results.

The F-criterion was determined using Formula 1 developed by Kyveryalg (1980):

$$
F_{\text {emp }}=\frac{\sigma_{1}^{2}}{\sigma_{2}{ }^{2}}
$$

where $\sigma_{1}^{2}-$ greater variance; $\sigma_{2}^{2}-$ smaller variance. 
We used Formula 2 to calculate the variance.

$$
\sigma^{2}=\frac{\sum f\left(x_{i}-\bar{x}\right)^{2}}{N}
$$

where $f$-the number of students with a certain level (indicated by the numerical indicators " 5 ", "4", “3") of professional culture development in law students; the indicator "2" was used to indicate the lack of professional culture in law students; $\left(x_{i}-x\right)$ - the difference between the numerical values $(5,4,3,2)$ and the value of the mean indicator (MI) of professional culture in law students; $\mathrm{N}$ - the number of students in those categories of groups (control or experimental) where the variance was calculated.

The results of the calculations to determine the F-criterion for the control and experimental groups are shown in Table 2.

Table 2. Results of the calculation of F-criterion

\begin{tabular}{|c|c|c|c|c|c|c|c|c|c|c|c|c|c|}
\hline \multirow{3}{*}{ Group } & \multirow{3}{*}{$\begin{array}{l}\text { Control type and } \\
\text { number of } \\
\text { students }\end{array}$} & \multirow{3}{*}{ MI } & \multicolumn{10}{|c|}{ Indicators used for determining F-criteria } & \multirow{3}{*}{$\mathrm{F}_{\text {crit }}$} \\
\hline & & & \multicolumn{4}{|l|}{$f$} & \multicolumn{4}{|c|}{$\left(x_{i}-x\right)$} & \multirow[b]{2}{*}{$\sum f\left(x_{i}-\bar{x}\right)^{2}$} & \multirow{2}{*}{$\sigma^{2}$} & \\
\hline & & & 5 & 4 & 3 & 2 & 5 & 4 & 3 & 2 & & & \\
\hline \multirow{2}{*}{ CG } & $\begin{array}{l}\text { IC } \\
105\end{array}$ & 3.6 & 10 & 43 & 52 & 0 & 1.4 & 0.4 & -0.6 & -1.6 & 45.2 & 0.43 & \multirow{3}{*}{1.08} \\
\hline & $\mathrm{FC}$ & 369 & & & & & & & & & & & \\
\hline \multirow{3}{*}{ EG } & 104 & & 13 & 46 & 45 & 0 & 1.31 & 0.31 & -0.69 & -1.69 & 48.15 & 0.46 & \\
\hline & IC & 3.57 & 9 & 44 & 55 & 0 & 1.43 & 0.43 & -0.57 & -1.57 & 44.41 & 0.41 & \multirow[b]{2}{*}{1.33} \\
\hline & $\begin{array}{l}\text { FC } \\
107\end{array}$ & 4.16 & 39 & 46 & 22 & 0 & 0.84 & -0.16 & -1.16 & -2.16 & 58.3 & 0.55 & \\
\hline
\end{tabular}

The analysis of the indicators in Table 2 allows summarizing that the variance at the incoming control (IC) stage in the control groups $\left(\sigma_{1}{ }^{2}\right)$ is 0.43 , and the variance at the final control (FC) stage in the CGs $\left(\sigma_{2}{ }^{2}\right)$ is 0.46 . Therefore, the calculation of the F-criterion $\left(\mathrm{F}_{\text {crit }} \mathrm{CG}\right)$ for the control groups according to the formula of Kyveryalg (1980) gave a figure of 1.08 .

The calculations made in order to specify the value of the variance in the groups where the experimental method of developing professional competence was introduced at the stage of the initial test (when joining the experiment) allowed determining its indicator - 0.41. In turn, at the end of the experiment (the final test of the level of development of professional culture) - we obtained a value of 0.55 . Therefore, the groups where the future lawyers studied with the use of the author's method, based on the realization of certain pedagogical conditions, $\mathrm{F}_{\text {crit }}-\mathrm{EG}$ ) had the value of 1.33 .

These indicators were tested to prove the probability of the author's conclusions. For this purpose, we compared the values of the $\mathrm{F}$-criterion $\left(\mathrm{F}_{\text {crit }} \mathrm{CG}\right.$ and $\left.\mathrm{F}_{\text {crit }} \mathrm{EG}\right)$ with the values of the theoretical F-criterion given in a special table (Kyveryalg, 1980).

$\mathrm{F}_{\text {crit }}$ was determined in our study by the number of degrees of freedom. In the control groups, the number of degrees of freedom for the numerator (larger variance) was 104 and 103, and for the experimental groups - 107 and 106 (one was deducted from the number of students in the control or experimental groups). According to the mentioned table, if the number of degrees of freedom of the numerator is in the range from 24 to infinity, and the lower value (denominator) varies from 60 to 120 , which corresponds to the figures in our study, the $\mathrm{F}_{\text {crit }}$ is determined in the range from 1.7 to 1.3 . It was found In the process of calculations that the value of $\mathrm{F}_{\text {crit }} \mathrm{EG}=1.33$ is within the outlined range. The obtained conclusion proves that the results of realization of pedagogical conditions for the development of professional culture in law students are probable and indicate the reliability of our experimental study.

$\mathrm{F}_{\text {crit }} \mathrm{CG}$ with a value of 1.08 goes beyond the probability, so the slight increase in the level of professional culture in law students who have studied in the control groups is related to the conditions of the traditional learning process. 


\section{Conclusions}

Therefore, we can state that the effectiveness of the development of professional culture in law students depends on the purposeful application of the proposed pedagogical conditions. Therefore, the effectiveness of our experimental study is confirmed by reliable indicators that have been verified using mathematical statistics. Comparing the indicators of the level of development of the professional culture of future lawyers in the experimental and control groups, we can conclude that the proposed set of pedagogical conditions contributes to a significant increase in its level.

\section{Prospects for Further Research}

Further scientific researchers are seen in the continuation of the improvement of the method of developing professional culture among of law students in the process of professional training of future lawyers at the senior years of study.

\section{References}

Annan-Diab, F. \& Molinari, C. (2017). Interdisciplinarity: Practical approach to advancing education for sustainability and for the sustainable development goals. The International Journal of Management Education, 15(2), 73-83. https://doi.org/10.1016/j.ijme.2017.03.006

Bakhov, I. S. (2014). Dialogue of cultures in multicultural education. World Applied Sciences Journal, 29(1), 106-109. https://doi.org/10.5829/idosi.wasj.2014.29.01.13775

Bartoli, C. (2015). The Italian legal clinics movement: Data and prospects. International Journal of Clinical Legal Education, 22(2). http://doi.org/10.19164/ijcle.v22i2.427

Bautista, L. (2014). The Socratic method as a pedagogical method in legal education. Research Paper. Wollongong, Australia: University of Wollongong.

Bhabha, F. (2015). Towards a Pedagogy of Diversity in Legal Education. Osgoode Hall Law Journal, 52(1), 59-108.

Bondarenko, S., Bodenchuk, L., Krynytska, O., \& Gayvoronska, I. (2019). Modelling instruments in risk management. International Journal of Civil Engineering and Technology, 10(1), 1561-1568.

Bratkova, O. I. (2018). Scientific approaches for preparing future lawyers to professional interaction. Bulletin of Zhytomyr Ivan Franko State University. Pedagogical Sciences, 4(95), 41-44. https://doi.org/10.35433/pedagogy. 4(95).2018.41-44

Bryant, S., Milstein, E., \& Shalleck, A. (2014). Transforming the education of lawyers: the theory and practice of clinical pedagogy. Durham, NC: Carolina Academic Press.

Fernandes, P. (2015). Curricular contextualization: Tracking the meanings of a concept. The Asia-Pacific Education Researcher, 22(4), 417-425. https://doi.org/10.1007/s40299-012-0041-1

Finkelstein, J. G. (2015). Practice in the Academy: Creating "Practice Aware". Law Graduates, 64, 643-644.

Fornell, C., \& Larcker, D. F. (1981). Evaluating structural equation models with unobservable variables and measurement error. Journal of Marketing Research, 18(1), 39-50. https://doi.org/10.1177/002224378101800104

Giamellaro, M. (2014). Primary contextualization of science learning through immersion in content-rich settings. International Journal of Science Education, 36(17), 2848-2871. https://doi.org/10.1080/09500693.2014.937787

Greiner, D. J., Pattanayak, C. W., \& Hennessy, J. (2013). The limits of unbundled legal assistance: a randomized study in a Massachusetts district court and prospects for the future. Harvard Law Review, 126, 901-989. https://doi.org/10.2139/ssrn.1948286

Jacobowitz, J. L. (2015). Lawyers beware: you are what you post - The case for integrating cultural competence, legal ethics, and social media. Science and Technology Law Review, 17, 541-580.

Jones, E., McFaul, H., \& Ryan, F. (2017). Clinical legal education in the United Kingdom: Origins, growth and the technological innovations and challenges of its future. German Journal of Legal Education, 4, 107-136.

Josephsen, J. (2015). Cognitive load theory and nursing simulation: An integrative review. Simulation in Nursing, 11(5), 259-267. https://doi.org/10.1016/j.ecns.2015.02.004

Kalaur, I., Sloma, V., \& Hnativ, O. (2017) Peculiarities of law students' professional motivation. Science and Education, 9, 94-99.

Khushbakhtov, A. Kh. (2015). The terminology “pedagogical conditions”. Young scientist, 23, 120-122. 
Kozhemiako, N. V. (2013). Method of communicative competence formation of future specialists in the field of law during the study of psychological and pedagogical disciplines. Main problems of technology and professional education, 4(1), 413-417.

Kyveryalg, A. A. (1980). Research methods in professional pedagogy. Tallinn, Estonia: Valgus.

Maharg, P. (2016). Transforming legal education: learning and teaching the law in the early twenty-first century. London, UK: Routledge. https://doi.org/10.4324/9781315235752

Maravilhas, S. (2015). Challenges for education in the information society (3rd ed). Hershey, PA: IGI Global.

Nasilenko, L. (2014). Forming the future lawyers' communicative competence: the experience of higher education in Ukraine and Germany. Comarative Professional Pedagogy, 4(3), 89-94. https://doi.org/10.2478/rpp-2014-0041

Olasolo, H., \& Wilson, R. J. (2016). Legal clinics in Continental Western Europe: The approach of the utrecht legal clinic on conflict, human rights, and international justice. Proceedings of the ASIL Annual Meeting, 104, 98-101. https://doi.org/10.5305/procannmeetasil.104.0098

Romanenko, Y. O., \& Chaplay, I. V. (2016). Marketing communication system within public administration mechanisms. Actual Problems of Economics, 178(4), 69-78.

Salomatin, A. (2015) (Ed.). Comparative legal policy: Preliminary concepts. Moscow, Russia: A-project.

Shay, G. (2015). Inside-out as law school pedagogy. Journal of Legal Education, 62(2), 207-217.

Strevens, C., \& Field, R. (2019) (Eds.). Educating for well-being in law: positive professional identities and practice. London: Routledge. https://doi.org/10.4324/9781351104401

Svetlichny, E. G. (2016). The concept of contextual education as a theoretical basis for the training of a specialist in the field of jurisprudence. Problems of modern teacher education, 50(2), 127-132

Tække, J., \& Paulsen, M. (2017). Digitalisation of education - the theory of the three waves. Aarhus, Denmark: The Centre for Internet Research Aarhus.

Tejedor, G., Segalas, J., \& Rosas-Casals, M. (2018). Transdisciplinarity in higher education for sustainability: How discourses are approached in engineering education. Journal of Cleaner Production, 175, 29-37. https://doi.org/10.1016/j.jclepro.2017.11.085

Tsiganyi, S. O. (2016) Model of forming the culture of vocational and legal communication in future lawyers in the process of professional training. Bulletin of the Cherkasy Bohdan Khmelnytsky National University. Series "Pedagogical Sciences", 15, 124-131.

Verbitskiy, A. (2015). The theory and practice of context education: Russia and the USA. Pedagogy and Psychology of Education, 1, 5-14.

Zoshiy, I. V. (2018). Formation of professional competence of future lawyers. Young scientist, 3(2), 487-492. 